DOI: https://doi.org/10.47631/jareas.v2i1.197

\title{
Food Security Index For Economic Community of West-African States (ECOWAS)
}

\author{
Bhola Khan ${ }^{1}$ \\ ${ }^{1}$ Department of Economics, Yobe State University, Damaturu, Nigeria
}

\begin{tabular}{|c|c|}
\hline Article Info & Abstract \\
\hline Article history: & Purpose: In this article attempt is made to develop a composite food security \\
\hline 10 December 2020 & index for some selected countries of the Economic Community of West-African \\
\hline Revised: 05 February 2021 & States (ECOWAS), e.g. Nigeria, Niger, Benin, and Ghana. The study also aims \\
\hline Accepted: 06 Febr & $\begin{array}{l}\text { to study the stability property of the indicators of composite food security } \\
\text { index. }\end{array}$ \\
\hline$\overline{\text { Keyw }}$ & Approach/Methodology/Design: For constructing a composite food security \\
\hline Composite Food Security & index for ECOWAS, one can use the basic methodology already developed by \\
\hline Index, & IFAD but in a modified form. This study is also based on IFAD methodology \\
\hline $\begin{array}{l}\text { ECOWAS, } \\
\text { Stabilitv }\end{array}$ & $\begin{array}{l}\text { but with one more additional variable that is political stability index and } \\
\text { assigned weight on the basis of Princinal Component Analysis (PCA). }\end{array}$ \\
\hline $\begin{array}{l}\text { Stability, } \\
\text { Trends, }\end{array}$ & Findings: This composite index is an improvement over all the other food \\
\hline Political Stab & $\begin{array}{l}\text { security index developed by others eminent economists and institutions from } \\
\text { time to time. This index consists of six indicators such as food availability, }\end{array}$ \\
\hline JEL: O10, O11, O13 & $\begin{array}{l}\text { food production, self-sufficiency of food, inverse relative price index, child } \\
\text { survival index, and political stability to construct the composite food security }\end{array}$ \\
\hline Paper Type : & $\begin{array}{l}\text { index of ECOWAS. Political stability is an additional indicator in the index of } \\
\text { ECOWAS. With the help of this index, the trends, stability and situation of }\end{array}$ \\
\hline Research Article & $\begin{array}{l}\text { food security index in region are discussed and analyzed from } 2001 \text { to } \\
\text { 2018. After careful analysis of composite food security index of ECOWAS, one }\end{array}$ \\
\hline Corresponding Author: & $\begin{array}{l}\text { can find out that It has quite impressive and improving gradually. } \\
\text { Practical Implication: This study provides strong suggestion about how these }\end{array}$ \\
\hline Bhola Khan & $\begin{array}{l}\text { five indicators of composite food security index provide an overview for the } \\
\text { selected countries to secure their level of food security in their respective }\end{array}$ \\
\hline Email: & $\begin{array}{l}\text { country. } \\
\text { Originality/Value: After the careful analysis of the collected data, it can be }\end{array}$ \\
\hline bhol & $\begin{array}{l}\text { concluded that the composite food security index plays an important role to } \\
\text { understand whether food security index is improving in respective countries } \\
\text { or not. }\end{array}$ \\
\hline
\end{tabular}

\section{Introduction}

Hunger is rising continuously world-wide, and the absolute number of undernourished people, i.e. those facing chronic food deprivation, has increased to nearly 821 million in 2017 from around 804 million in 2016 (FAO, 2018). The situation is worsening in South America and most of the regions of Africa (Table 1). Africa remains the continent with the highest Prevalence of Undernourishment (PoU), affecting almost 21 percent of the population (more than 256 million people) (FAO, 2017). The situation is also deteriorating in South America, where the PoU has increased from 4.7 percent in 2014 to a projected 5.0 percent in 2017. Asia's decreasing trend in undernourishment seems to be slowing down significantly. The projected PoU for Asia in 2017 is 11.4 percent, which represents more than 515 million people (FAO, 2018). Without increased

Copyright ( 2021, Journal of Advanced Research in Economics and Administrative Sciences (JAREAS), Under a 
efforts, the world will fall far short of achieving the SDG target of eradicating hunger by 2030 .

The Economic Community of West African States (ECOWAS) is a regional group of 15 countries like other group of countries. It was founded in 1975 and its objective is to promote economic integration in "all fields of economic activity, particularly industry, transport, telecommunications, energy, agriculture, natural resources, commerce, monetary and financial questions, social and cultural matters. West Africa has become the fastest-growing region of the African continent, with economic growth rate of 6.7 percent in 2013 and 7.4 percent forecast for 2014 (African Economic Outlook, 2013). Though the oil and other minerals are playing a vital role in economic growth of the ECOWAS but most of the population's livelihoods of this region depends on agriculture activities and this sector is still the major source of food, income and livelihood of the ECOWAS population. However, the food production of this region is unable to meet the growing demand of the community. Therefore, the region needs to import about the 20 percent of the food consumed (OECD/SWAC, 2013) to meet the growing demand for more foods.

In this region, the prevalence of hunger and malnutrition is shared out by the Millennium Development Goals. In spite of these efforts the supply of food remains critical in absolute terms, with more than 36 million people of this region badly suffering from food grain and they remain malnourished. In 2008, due to the hike in food prices the level of food security was seriously affected across the world and in most of the developing countries where people were bound to live on less than a dollar. The main factors responsible for imbalance of food are the price hike, poor harvest of crops in the major agriculture regions, increase in demand for food in China and India, diversification of food crops from human consumption to biofuel and manufacturing animal feed were also significant factors (Iqbal \&Amjad, 2009). Therefore, 44 million people were pushed to poverty (World Bank) as a result of food price hike, and thus imbalance between demand of food and supply was created. Apart from the food supply imbalance, the region suffers from serious climate and man-made challenges, such as droughts, floods and civil crisis. These frequently lead the region to food deficit situation and further food insecurity (FAO, 2014). Nevertheless, the region started making balance in their food supply and for this they made a strong political association among the region to reduce the dependency on food import. They started intra-regional trade of food.

One can see the prevalence of undernourishment in the world and various regions of the world in table 1 below.

Table 1: Prevalence of Undernourishment in the World, 2005-2017

\begin{tabular}{|l|c|c|c|c|c|c|}
\hline \multicolumn{7}{|c|}{ Prevalence of undernourishment (\%) } \\
\hline & $\mathbf{2 0 0 5}$ & $\mathbf{2 0 1 0}$ & $\mathbf{2 0 1 2}$ & $\mathbf{2 0 1 4}$ & $\mathbf{2 0 1 6}$ & $\mathbf{2 0 1 7}^{\mathbf{1}}$ \\
\hline World & 14.5 & 11.8 & 11.3 & 10.7 & 10.8 & 10.9 \\
\hline Africa & $\mathbf{2 1 . 2}$ & $\mathbf{1 9 . 1}$ & $\mathbf{1 8 . 6}$ & $\mathbf{1 8 . 3}$ & $\mathbf{1 9 . 7}$ & $\mathbf{2 0 . 4}$ \\
\hline Northern Africa & 6.2 & 5.0 & 8.3 & 8.1 & 8.5 & 8.5 \\
\hline
\end{tabular}

Copyright (C) 2021, Journal of Advanced Research in Economics and Administrative Sciences (JAREAS), Under a 


\begin{tabular}{|l|c|c|c|c|c|c|}
\hline Sub-Saharan Africa & 24.3 & 21.7 & 21.0 & 20.7 & 22.3 & 23.2 \\
\hline Eastern Africa & 34.3 & 31.3 & 30.9 & 30.2 & 31.6 & 31.4 \\
\hline Middle Africa & 32.4 & 27.8 & 26.0 & 24.2 & 25.7 & 26.1 \\
\hline Southern Africa & 6.5 & 7.1 & 6.9 & 7.4 & 8.2 & 8.4 \\
\hline Western Africa & 12.3 & 10.4 & 10.4 & 10.7 & 12.8 & 15.1 \\
\hline Asia & $\mathbf{1 7 . 1}$ & $\mathbf{1 3 . 6}$ & $\mathbf{1 2 . 9}$ & $\mathbf{1 2 . 0}$ & $\mathbf{1 1 . 5}$ & $\mathbf{1 1 . 4}$ \\
\hline Central Asia & 11.1 & 7.3 & 6.2 & 5.9 & 6.0 & 6.2 \\
\hline Eastern Asia & 14.1 & 11.2 & 9.9 & 8.8 & 8.5 & 8.5 \\
\hline South-eastern Asia & 18.1 & 12.3 & 10.6 & 9.7 & 9.9 & 9.8 \\
\hline Southern Asia & 21.5 & 17.2 & 17.1 & 16.1 & 15.1 & 14.8 \\
\hline Western Asia & 9.4 & 8.6 & 9.5 & 10.4 & 11.1 & 11.3 \\
\hline Central Asia and Southern Asia & 21.1 & 16.8 & 16.7 & 15.7 & 14.7 & 14.5 \\
\hline Eastern Asia and South-eastern Asia & 15.2 & 11.5 & 10.1 & 9.0 & 8.9 & 8.9 \\
\hline Western Asia and Northern Africa & 8.0 & 7.1 & 8.9 & 9.3 & 9.9 & 10.0 \\
\hline Latin America And The Caribbean & $\mathbf{9 . 1}$ & $\mathbf{6 . 8}$ & $\mathbf{6 . 4}$ & $\mathbf{6 . 2}$ & $\mathbf{6 . 1}$ & $\mathbf{6 . 1}$ \\
\hline Caribbean & 23.4 & 19.8 & 19.3 & 18.5 & 17.1 & 16.5 \\
\hline Latin America & 8.1 & 5.9 & 5.4 & 5.3 & 5.3 & 5.4 \\
\hline Central America & 8.4 & 7.2 & 7.2 & 6.8 & 6.3 & 6.2 \\
\hline South America & 7.9 & 5.3 & 4.7 & 4.7 & 4.9 & 5.0 \\
\hline Oceania & $\mathbf{5 . 5}$ & $\mathbf{5 . 2}$ & $\mathbf{5 . 4}$ & $\mathbf{5 . 3}$ & $\mathbf{5 . 3}$ & $\mathbf{5 . 4}$ \\
\hline Northern America And Europe & $<\mathbf{2 . 5}$ & $<\mathbf{2 . 5}$ & $<\mathbf{2 . 5}$ & $<\mathbf{2 . 5}$ & $<\mathbf{2 . 5}$ & $<\mathbf{2 . 5}$ \\
\hline
\end{tabular}

${ }^{I}$ Projected Value

Source: Food Agriculture Organization, 2017

The purpose of this paper is to develop a composite food security index to measure the level of food security of ECOWAS. A large number of indicators for food security have been identified by the Food and Agriculture Organization (FAO). However, no attempt has been made to combine these indicators to develop and construct a composite food security index for measuring food security level of ECOWAS. However, the International Fund for Agriculture and Development (IFAD) has constructed a food security index for measuring food security of 114 countries using the following indicators (Khan, 2013):

- Per capita daily calorie supply

- Annual growth rate of per capita daily energy supply

- Food production index

- Self-sufficiency ratio

- Production variability

- Consumption variability

For constructing a composite food security index for ECOWAS, the basic methodology already developed by IFAD is usually used but in a modified form. On the basis of IFAD methodology, others like M. Iqbal and R. Amzad (2009) and Pakistan Task Force on Food Security also 
constructed food security index for SAARC countries and Pakistan as well, taking into account only four indicators like food availability index, food production index, self-sufficiency ratio index and inverse relative price index and they took weighted mean of the indicators giving arbitrary weights to the said four indicators. They assigned $1 / 2$ weight to each one and for this there is no sufficient reason to why these weights are being assigned to these indicators. In addition, Khan B. has also constructed a composite food security index for India using one additional indicator; that is, child survival rate index indicators. He also employed the Principal Components Analysis (PCA) to assign the appropriate weights to all five indicators.

This study is also based on IFAD Methodology but with one more additional variable; political stability index and assigned weight on the basis of Principal Component Analysis (PCA). The reason for including political stability index is that it is an important indicator concerning food security in ECOWAS region. If the political environment is stable, then the policy for the alleviation of poverty, unemployment, food security will be implemented properly. It may also give more positive results.

There are several other indicators that also affect food security of a country or of a region but in this article, due to lack of data, it is limited only up to six indicators which emphasize production, availability, self-sufficiency ratio, inverse related price ratio, child survival rate index, and political stability index.

\section{Methodology and Procedures}

In this study, two hypotheses are formulated as below:

RH1: Composite Food Security Index for ECOWAS has been stable since 2001.

RH2: The individual indices of food security, e.g., production of food, availability of food, inverse relative price index, self-sufficiency ratio index, child survival ratio index and political stability index have been stable since 2001 .

For calculating Composite Food Security Index for some selected countries of ECOWAS, first we took the indicators - per capita food production index, per capita food availability index, self-sufficiency ration index, inverse relative price index, child survival rate index, and political stability index. Out of six indices, four have been calculated, e.g., per capita food availability index, self-sufficiency ration index, inverse relative price index, child survival rate index and two have been taken from Food Agriculture Organization (FAOSTAT, 2019) and multiply with their Eigen values for the assigning of appropriate weight to both of them and after that their base years have been converted into 2001 so that one can easily compare whether the all indices or composite indices are improving or not. The other four indices, i.e. FAI, SSRI, IRFPI and CSRI, have been calculated on the basis of below formula and multiplied by their Eigen values for assigning the appropriate weight to them.

Copyright (C) 2021, Journal of Advanced Research in Economics and Administrative Sciences (JAREAS), Under a 


$$
\begin{array}{cc}
\text { FAI }=\frac{\text { Total Food Production }}{\text { Total Population }} * 100, & \text { Where FAI=Food Availability Index, } \\
\text { SSRI }=\frac{\text { Total Output }}{\text { Total Output }- \text { Export+Import }} * 100, & \text { Where, SSRI }=\text { Self-Sufficiency Ratio Index, } \\
\text { IRFPI }=\frac{\text { Consumer Price index }}{\text { Food } \text { Price Index }} * 100, & \text { Where, IRFPI }=\text { Inverse Relative Food Price Index, } \\
\text { CSRI }=\frac{1000-\text { UFMR }_{10}}{1000} 100, & \text { Where, CSRI }=\text { Child Survival Ratio Index. }
\end{array}
$$

For assigning weights to different indices, Principal Component Analysis (PCA) has been used (Khan, 2013). By means of rotated factor loading (pattern matrix), the following results were obtained. Values for the four ECOWAS countries are based on the robust Eigen values and in the table below only the highest values are presented.

Table 2: Principal Component Analysis (PCA) Results

\begin{tabular}{|c|c|c|c|c|}
\hline Variable & Nigeria (Eigen Value) & Niger (Eigen Value) & Benin (Eigen Value) & $\begin{array}{c}\text { Ghana (Eigen } \\
\text { Value) }\end{array}$ \\
\hline FAI & 4.172 & 3.79 & 3.54 & 3.83 \\
\hline FPI & 0.961 & 0.98 & 1.05 & 1.10 \\
\hline SSRI & 0.675 & 0.77 & 0.776 & 0.91 \\
\hline IRPS & 0.107 & 0.36 & 0.308 & 0.90 \\
\hline CMRI & 0.056 & 0.046 & 0.305 & 0.051 \\
\hline PSI & 0.030 & 0.04 & 0.497 & 0.008 \\
\hline
\end{tabular}

Source: Author's Calculations.

Table 2 shows factor loadings for all the four countries for giving weights to different indicators which are extracted by PCA; one can give weights to food production index, self-sufficiency ratio index, inverse relative price index, child survival rate index, and political stability ratio index. For constructing all six indices, the year 2001 can be used a base year for all four ECOWAS countries so that one can easily understand how per capita availability of food, per capita food production, inverse relative price index, child survival rate index, and political stability index are stable. With the help of these six indicators, one can calculate a composite food security index for Economic Community of West African States (ECOWAS) and further assume 2001 as a base year for it.

$$
\mathrm{CFSI}=\mathrm{FPI} . \mathrm{X}_{1}+\mathrm{FAI} \cdot \mathrm{X}_{2}+\mathrm{IRPI} . \mathrm{X}_{3}+\mathrm{SSRI} \cdot \mathrm{X}_{4}+\mathrm{CSRI} . \mathrm{X}_{5}+\mathrm{PSI} \cdot \mathrm{X}_{6}
$$

Where, $\mathrm{X}_{1}, \mathrm{X}_{2}, \mathrm{X}_{3}, \mathrm{X}_{4}, \mathrm{X}_{4}, \mathrm{X}_{6}$ are representing Eigen value.

\section{Results and Discussion}

The researcher calculated a composite food security index for some selected countries of ECOWAS with 2001 as a base year. The results indicate that food security index for Nigeria, Niger, Benin, and Ghana is gradually improving. For Nigeria in 2001, it was 100 that is base

Copyright (C) 2021, Journal of Advanced Research in Economics and Administrative Sciences (JAREAS), Under a 
year, and in 2015 it was the highest 214.24 (table 3, appendix). While in Niger in 2007, it was the highest, i.e., 185.33. After that, it started declining but it was always more than the base year. The situation of composite food security index in Benin is also impressive; it was the highest in 2016 reaching 191.92. In Ghana, the status of food security index also improved better than the base year 2001. It was the highest in 2018 recording 165.15 .

For checking stability of composite food security index of ECOWAS, the researcher applied Chow Test and calculated ' $F$ ' ratio and found that the index was stable in all four selected countries of ECOWAS since 2001. In this way the second research hypothesis has been satisfied. Similarly, stability for availability index, production index, self-sufficiency ratio index, inverse relative price index, child survival rate index, and political stability index have been tested, and it is found out that food production, food availability, child survival index and political stability index for Nigeria has been stable. However, self-sufficiency ratio and inverse relative price index is highly unstable (table 3, appendix).

While in Niger, food production, food availability and child survival were found stable, but selfsufficiency ratio, inverse relative price index, and political stability index has been found highly unstable (table 4, appendix). In Benin, food production and child survival are found stable, but other four variables have been unstable. Moreover, among the four, political stability has been highly unstable (table 5, appendix). Food production, food availability, child survival, and inverse relative price index have been found stable in Ghana, while self-sufficiency ratio and political stability were found unstable (table 6, appendix).

Therefore, it is concluded that some of the variables have been found stable in these four countries of ECOWAS and some are not found stable. Nevertheless, out of the four variables, political stability has been found highly unstable in Niger and Benin. To assign the appropriate weight for all the six indices, a Principal Component Analysis (PCA) technique was used; however, it has its own limitations. It may be less efficient since it neglects some information on correlation among the indicators. Even the indicators themselves may not be independent to each other (Khan, 2013).

Finally, to solve the problem of food insecurity in these countries, the government must introduce more new income generation programs and supervise the existing one in such a way that people have sufficient income. Therefore, they may have physical and economic access to sufficient and healthy food for their healthy and active life.

\section{Conclusion and Suggestion}

Agricultural and allied sector have more importance in the ECOWAS region. However, its contribution to GDP is minimal. Therefore, it is the responsibility of the concerned government of these countries to diversify their economy and put more focus on agriculture and allied

Copyright (C) 2021, Journal of Advanced Research in Economics and Administrative Sciences (JAREAS), Under a Creative Commons Attribution 4.0 International License 
activities so that the imports of food grain will be minimized and in future the region becomes self-dependent in terms of food production.

As indicated in the tables 3,4,5, and 6, the political stability is not very important for the composite food security index. It seems that it is not playing an important role in securing food security in the region. The reason behind this is that a significant amount of food grains for their consumption is imported by the ECOWAS countries. However, some of the countries of the region e.g. Nigeria and Ghana, are putting more focus on their agricultural activities. Nigeria in particular has started food import substitution policy, though it not fully implemented, but at least it has started.

\section{Conflict of Interest}

The authors declares no conflict of interest

\section{Funding}

None

Compliance with Ethical Standards: Not Applicable.

Ethical Approval: This article does not contain any studies with human participants or animals performed by any of the author.

\section{References}

African Economic Outlook (2013).

Economic Community of West African States (ECOWAS) Report, 2018.

Enrique de Loma-Ossorio, Carmen Lahoz and Luis F. Portillo, (2014), "Assessment of the Right to Food in the ECOWAS region", Institute of Hunger Studies, Food and Agriculture Organization of the United Nations Rome.

Iqbal, M., \& Amjad, R. (2012). Food security in South Asia: strategies and programmes for regional collaboration. In Regional integration and economic development in South Asia. Edward Elgar Publishing.

International Fund for Agriculture Development (IFAD), Rome, 2012.

Khan B. (2013), "A new food security index for India", Man \& Development, Centre for Research in Rural and Industrial Development, Chandigarh, India, Vol. XXXV No. 3, pp. 19-30,

Food Agriculture Organization, FAOSTAT, 2017 \& 2019.

UN ESA 2011, World Urbanization Prospects: The 2011 Revision. UN Dept. of Economic and

Social Affairs, Population Division (available at http://esa.un.org/unpd/wup/CDROM/Urban-Rural-Population.htm). Accessed 16 September 2014.

OECD/SWAC, 2013.

Copyright (C) 2021, Journal of Advanced Research in Economics and Administrative Sciences (JAREAS), Under a Creative Commons Attribution 4.0 International License 
UN ESA, (2013), "World Population Prospects: The 2012 Revision. UN Dept. of Economic and Social Affairs, Population Division. (available at http://esa.un.org/unpd/wpp/ExcelData/population.htm), Accessed 16 September 2014.

Sanitation facilities and drinking water sources, WHO/UNICEF, 2013.

World Development Indicators, World Bank Reports, 2017. 


\section{Appendix}

Table 3: Composite Food Security Index of Nigeria

\begin{tabular}{|c|c|c|c|c|c|c|c|}
\hline Year & FPI & FAI & SSRI & IRPI & CSRI & PSI & CFSI \\
\hline 2001 & 100 & 100 & 100 & 100 & 100 & 100 & $\mathbf{1 0 0 . 0 0}$ \\
\hline 2002 & 104.81 & 93.55 & 75.61 & 72.03 & 100.70 & 111.64 & $\mathbf{1 1 5 . 8 6}$ \\
\hline 2003 & 109.14 & 96.43 & 89.26 & 71.98 & 101.42 & 111.64 & $\mathbf{1 2 6 . 0 3}$ \\
\hline 2004 & 115.95 & 103.27 & 75.40 & 66.70 & 102.13 & 119.86 & $\mathbf{1 3 9 . 4 3}$ \\
\hline 2005 & 122.28 & 108.19 & 121.54 & 75.87 & 103.35 & 114.38 & $\mathbf{1 3 9 . 7 5}$ \\
\hline 2006 & 130.12 & 115.84 & 63.74 & 32.46 & 103.42 & 139.04 & $\mathbf{1 7 8 . 6 9}$ \\
\hline 2007 & 121.84 & 105.92 & 63.36 & 16.71 & 104.00 & 137.67 & $\mathbf{1 7 5 . 9 4}$ \\
\hline 2008 & 129.48 & 117.81 & 69.46 & 28.81 & 104.53 & 127.39 & $\mathbf{1 8 0 . 3 7}$ \\
\hline 2009 & 114.55 & 106.12 & 83.19 & 36.07 & 104.98 & 136.98 & $\mathbf{1 5 5 . 9 9}$ \\
\hline 2010 & 130.03 & 119.97 & 77.62 & 36.57 & 105.36 & 151.36 & $\mathbf{1 7 6 . 9 6}$ \\
\hline 2011 & 122.94 & 127.31 & 110.91 & 23.63 & 105.68 & 134.24 & $\mathbf{1 7 5 . 9 7}$ \\
\hline 2012 & 138.27 & 123.05 & 92.84 & 28.70 & 105.93 & 139.72 & $\mathbf{1 9 0 . 3 5}$ \\
\hline 2013 & 136.41 & 136.95 & 94.17 & 20.24 & 106.16 & 143.15 & $\mathbf{1 9 6 . 5 6}$ \\
\hline 2014 & 152.16 & 138.05 & 97.96 & 20.02 & 106.37 & 145.89 & $\mathbf{2 1 4 . 2 3}$ \\
\hline 2015 & 154.43 & 139.24 & 77.56 & 27.53 & 106.55 & 132.191 & $\mathbf{2 1 4 . 2 4}$ \\
\hline 2016 & 152.93 & 138.03 & 59.59 & 48.64 & 106.73 & 128.76 & $\mathbf{2 0 1 . 7 2}$ \\
\hline 2017 & 153.48 & 137.18 & 69.09 & 47.43 & 106.95 & 132.87 & $\mathbf{2 0 2 . 2 2}$ \\
\hline 2018 & 154.85 & 138.97 & 73.28 & 35.99 & 107.22 & 134.24 & $\mathbf{2 1 0 . 3 7}$ \\
\hline
\end{tabular}

Source: Author's Calculations

Table 4: Composite Food Security Index of Niger

\begin{tabular}{|c|c|c|c|c|c|c|c|}
\hline Year & FPI & FAI & SSRI & IRPI & CSRI & PSI & CFSI \\
\hline 2001 & 100.00 & 100.00 & 100.00 & 100.00 & 100.00 & 100.00 & $\mathbf{1 0 0 . 0 0}$ \\
\hline 2002 & 106.98 & 112.42 & 114.34 & 141.04 & 100.10 & -108.33 & $\mathbf{1 1 4 . 9 7}$ \\
\hline 2003 & 103.85 & 105.26 & 120.43 & 160.21 & 100.22 & 33.33 & $\mathbf{1 1 7 . 9 9}$ \\
\hline 2004 & 94.77 & 102.28 & 133.04 & 144.05 & 100.34 & -425 & $\mathbf{1 1 4 . 8 9}$ \\
\hline 2005 & 105.84 & 110.99 & 106.52 & 135.32 & 100.45 & -408.33 & $\mathbf{1 1 1 . 8 2}$ \\
\hline 2006 & 109.64 & 116.23 & 100 & 100 & 100.57 & -191.66 & $\mathbf{1 0 5 . 2 8}$ \\
\hline 2007 & 111.87 & 132.60 & 132.60 & 448.94 & 100.67 & -383.33 & $\mathbf{1 8 5 . 3 3}$ \\
\hline 2008 & 129.23 & 136.23 & 102.17 & 255.91 & 100.77 & -558.33 & $\mathbf{1 4 4 . 8 6}$ \\
\hline 2009 & 102.89 & 112.26 & 115.21 & 286.49 & 100.87 & -958.33 & $\mathbf{1 4 3 . 5 3}$ \\
\hline 2010 & 125.96 & 125.99 & 108.70 & 276.31 & 100.96 & -966.66 & $\mathbf{1 4 7 . 5 7}$ \\
\hline 2011 & 106.96 & 113.03 & 98.04 & 362.17 & 100.96 & -733.33 & $\mathbf{1 5 6 . 2 2}$ \\
\hline 2012 & 112.42 & 118.58 & 91.09 & 310.71 & 101.10 & -958.33 & $\mathbf{1 4 6 . 7 7}$ \\
\hline 2013 & 11.41 & 115.37 & 98.06 & 430.04 & 101.10 & -1100 & $\mathbf{1 7 1 . 1 8}$ \\
\hline 2014 & 111.99 & 116.70 & 91.08 & 435.68 & 101.20 & -983.33 & $\mathbf{1 7 1 . 3 2}$ \\
\hline 2015 & 114.24 & 118.99 & 98.06 & 356.26 & 101.25 & -891.66 & $\mathbf{1 5 7 . 7 5}$ \\
\hline 2016 & 118.06 & 123.89 & 82.78 & 216.17 & 101.29 & -916.66 & $\mathbf{1 2 8 . 4 3}$ \\
\hline 2017 & 121.21 & 122.47 & 97.26 & 212.72 & 101.42 & -1083.33 & $\mathbf{1 3 1 . 0 0}$ \\
\hline 2018 & 118.02 & 124.87 & 78.44 & 216.55 & 101.32 & -1000 & $\mathbf{1 2 7 . 8 3}$ \\
\hline
\end{tabular}

Source: Author's Calculations 
Table 5: Composite Food Security Index of Benin

\begin{tabular}{|c|c|c|c|c|c|c|c|}
\hline Year & FPI & FAI & SSRI & IRPI & CSRI & PSI & CFSI \\
\hline 2001 & 100.00 & 100.00 & 100.00 & 100.00 & 100.00 & 100.00 & $\mathbf{1 0 0 . 0 0}$ \\
\hline 2002 & 111.68 & 120.48 & 151.61 & 106.18 & 100.122 & 102.5 & $\mathbf{1 1 1 . 9 0}$ \\
\hline 2003 & 103.20 & 112.71 & 215.32 & 114.68 & 100.123 & 85 & $\mathbf{1 1 3 . 8 7}$ \\
\hline 2004 & 106.98 & 120.12 & 194.35 & 112.50 & 100.123 & 33.75 & $\mathbf{1 1 4 . 1 4}$ \\
\hline 2005 & 108.86 & 118.05 & 307.25 & 121.35 & 100.123 & 56.25 & $\mathbf{1 2 5 . 3 8}$ \\
\hline 2006 & 99.30 & 102.04 & 630.64 & 57.31 & 100.124 & 68.75 & $\mathbf{1 4 6 . 7 2}$ \\
\hline 2007 & 102.43 & 106.11 & 556.45 & 38.91 & 100.124 & 48.75 & $\mathbf{1 4 0 . 8 4}$ \\
\hline 2008 & 111.29 & 135.34 & 592.74 & 52.77 & 100.124 & 46.25 & $\mathbf{1 5 1 . 4 5}$ \\
\hline 2009 & 129.46 & 139.39 & 473.38 & 96.11 & 100.124 & 50 & $\mathbf{1 5 0 . 0 3}$ \\
\hline 2010 & 111.13 & 144.71 & 94.35 & 71.21 & 100.124 & 32.5 & $\mathbf{1 0 7 . 5 8}$ \\
\hline 2011 & 129.89 & 154.01 & 858.87 & 49.05 & 100.125 & 40 & $\mathbf{1 8 5 . 0 8}$ \\
\hline 2012 & 128.58 & 165.17 & 533.06 & 57.74 & 100.125 & 45 & $\mathbf{1 5 6 . 3 3}$ \\
\hline 2013 & 149.29 & 178.60 & 766.12 & 43.25 & 100.125 & 37.5 & $\mathbf{1 8 6 . 7 3}$ \\
\hline 2014 & 131.73 & 187.62 & 779.83 & 42.01 & 100.125 & 3.75 & $\mathbf{1 8 1 . 9 3}$ \\
\hline 2015 & 121.72 & 175.22 & 779.19 & 55.73 & 100.126 & -1.25 & $\mathbf{1 7 7 . 1 2}$ \\
\hline 2016 & 134.07 & 183.31 & 865.32 & 82.42 & 100.126 & 0 & $\mathbf{1 9 1 . 9 2}$ \\
\hline 2017 & 134.66 & 181.68 & 853.22 & 85.50 & 100.126 & 6.25 & $\mathbf{1 9 1 . 0 0}$ \\
\hline 2018 & 135.51 & 180.64 & 831.45 & 86.89 & 100.126 & 7 & $\mathbf{1 8 9 . 2 9}$ \\
\hline
\end{tabular}

Source: Author's Calculations

Table-6: Composite Food Security Index of Ghana

\begin{tabular}{|c|c|c|c|c|c|c|c|}
\hline Year & FPI & FAI & SSRI & IRPI & CSRI & PSI & CFSI \\
\hline 2001 & 100 & 100 & 100 & 100 & 100 & 100 & $\mathbf{1 0 0}$ \\
\hline 2002 & 127.84 & 102.63 & 100.01 & 110.97 & 100.0003 & 44.44 & $\mathbf{1 1 8 . 8 5}$ \\
\hline 2003 & 108.97 & 104.38 & 99.98 & 129.20 & 100.0006 & -8.33 & $\mathbf{1 1 4 . 4 1}$ \\
\hline 2004 & 108.97 & 105.26 & 99.97 & 142.77 & 100.0009 & -11.11 & $\mathbf{1 0 7 . 3 0}$ \\
\hline 2005 & 117.90 & 107.017 & 99.98 & 159.57 & 100.0011 & -47.22 & $\mathbf{1 1 3 . 6 2}$ \\
\hline 2006 & 114.34 & 108.77 & 99.99 & 222.46 & 100.0014 & -2.77 & $\mathbf{9 8 . 5 5}$ \\
\hline 2007 & 97.09 & 109.64 & 99.98 & 253.22 & 100.0016 & 19.44 & $\mathbf{1 0 1 . 0 6}$ \\
\hline 2008 & 136.73 & 112.28 & 100.00 & 320.25 & 100.0019 & 8.33 & $\mathbf{1 2 7 . 8 3}$ \\
\hline 2009 & 157.88 & 114.91 & 100.00 & 346.96 & 100.0022 & -8.33 & $\mathbf{1 4 2 . 3 8}$ \\
\hline 2010 & 177.67 & 118.42 & 100.00 & 358.06 & 100.0025 & -8.33 & $\mathbf{1 5 6 . 1 9}$ \\
\hline 2011 & 160.90 & 118.42 & 99.99 & 414.08 & 100.0029 & -47.22 & $\mathbf{1 4 5 . 4 7}$ \\
\hline 2012 & 175.58 & 118.421 & 100.01 & 415.75 & 100.0032 & -36.11 & $\mathbf{1 5 5 . 0 5}$ \\
\hline 2013 & 172.08 & 117.54 & 99.99 & 473.68 & 100.0035 & -16.66 & $\mathbf{1 5 2 . 7 9}$ \\
\hline 2014 & 175.54 & 117.54 & 99.99 & 645.53 & 100.0038 & 30.55 & $\mathbf{1 5 5 . 7 4}$ \\
\hline 2015 & 176.08 & 116.66 & 99.99 & 766.83 & 100.0041 & 8.33 & $\mathbf{1 5 6 . 3 6}$ \\
\hline 2016 & 180.55 & 116.66 & 99.99 & 931.92 & 100.0043 & 36.11 & $\mathbf{1 5 9 . 9 4}$ \\
\hline 2017 & 182.22 & 118.42 & 99.99 & 865.19 & 100.0045 & -25.00 & $\mathbf{1 6 1 . 1 9}$ \\
\hline 2018 & 186.85 & 120.17 & 99.99 & 991.60 & 100.0047 & -22.22 & $\mathbf{1 6 5 . 1 5}$ \\
\hline
\end{tabular}

Source: Author's Calculations 